\title{
FILICES PURDOMIANAE
}

\author{
CARL CHRISTENSEN
}

(The ferns collected by Mr. William PuRdom in rgro in Shensi during the Arnold Arboretum expedition to northern China have been placed in the hands of Dr. CARL Christensen of Copenhagen. His report upon them is found in the following paper.-C. S. SARGEnT, Arnold Arboretum.)

\section{Alphabetical list of species}

The species marked by an asterisk are probably new to the province of Shensi.

I. Adiantum aristatum Christ.-Tai-pei-shan, no. 79 .

2. A. erythrochlamys Diels.-Tai-pei-shan, no. 78 .

3. A. pedatum L.-Tai-pei-shan, nos. 7I, 80.

4. Asplenium adiantum nigrum L.-No. 74 .

5. A. Sarelii Hook.-Nos. $73,76$.

6. A. varians Hook. et Grev.-No. 75 .

7. A. trichomanes L.-Tai-pei-shan, no. 77 .

8. *Athyrium acrostichoides (Sw.) Diels.-No. 49.

9. A. Biondii Christ.-Tai-pei-shan, no. 43.

Io. A. crenatum (Sommerf.) Rupr.-Northern Chili, no. 64 .

II a. A. filix-femina (L.) Roth.-No. 48.

II $b$. A. filix-femina (L.) Roth var. multidentatum (Döll).No. 62 .

12. *A. Henryi (Bak.) Diels.-Tai-pei-shan, no. 42.

I3. *A. mongolicum (Franch.) Diels var. Purdomii, var. nov.Nos. $13,20$.

I4. *A. Sargentii, sp. nov.-Tai-pei-shan, no. Iо. 58,60 .

I5. A. spinulosum (Maxim.) Milde.-Tai-pei-shan, nos. 57,

I6. (?) A. subsimile Christ.-No. 50 .

I7. Blechnum eburneum Christ.-WILson no. $47^{23}$.

I8. Cheilanthes argentea (Christ) Hook.-Wirson no. 4724.

I9. C. lanceolata, sp. nov.-Tai-pei-shan, nos. 24, 25 .

20. Cheilanthes sp. - No. I5. 
21. Coniogramme fraxinea (Don.) Diels.-No. 82 .

22. Cryptogramma Stelleri (Gmel.) Prantl.-Tai-pei-shan, no. 72.

23. Cyclophorus pekinensis C. Chr.-No. 91 .

24. C. Sheareri (Bak.) C. Chr.-Tai-pei-shan, no. 97.

25. C. taeniodes C. Chr.-No. 83 .

-. C. taeniodes var. furcata.-No. 89 .

26. Cystopteris fragilis (L.) Bernh.-No. 47.

27. ${ }^{*}$ C. moupinensis Franch.-Tai-pei-shan, nos. 14, 63.

28. * Doryopteris concolor (Langsd. et Fisch.) Kuhn.-No. I6.

29. Drynaria reducta Christ.-No. 87 .

30. Dryopteris lacera (Thunb.) C. Chr.-No. 68.

3r. * D. Linnaeana C. Chr.-Nos. 35,45 .

32. * (?) D. marginata (Wall.) Christ.-No. 67.

33. * D. nipponica (Franch. et Sav.) C. Chr.-Tai-pei-shan, no. 38 .

34. * D. oyamensis (Bak.) C. Chr.-Tai-pei-shan, no. 88.

35. ${ }^{*} D$. phegopteris (L.) C. Chr.-No. 70; new to China proper.

36. D. polylepis (Franch. et Sav.) C. Chr.-Tai-pei-shan, nos. 37,55 .

37. * D. Purdomii, sp. nov.-Tai-pei-shan, no. 44.

38. ${ }^{*}$ D. sericea, sp. nov.-Tsin-ling, no. 66.

39. Gymnopteris bipinnata Christ.-Tai-pei-shan, no. 28. 9, I2.

40. Matteuccia intermedia, sp. nov.-Tai-pei-shan, nos. I, 8,

4r. Microlepia Wilfordii Moore.-No. 69.

42. * Polypodium (Goniophl.) amoenum Wall.-No. 85 .

43. P. (Gon.) subamoenum Clarke var. chinense Christ.Tai-pei-shan, no. 32 .

44. *P. (Pleopeltis) clathratum Clarke.-Tai-pei-shan, no. $9^{6 .}$ 45. P. (Pl.) eilophyllum Diels.-No. 90.

46. $P$. (Pl.) lineare Thunb.-Tai-pei-shan, no. 93.

46a. P. (Pl.) lineare var. contorlum Christ.-Nos. 92, 94.

47. P. (Pl.) oligolepidum Bak.-No. 95.

48. P. (Pl.) shensiense Christ.-No. 84 .

49. Polystichum acanthophyllum (Franch.) Christ.-Nos. 2I, 52 (in part), $54,56,34$ (?).

50. P. aculeatum (L.) Roth.-No. 6r. 
51. P. Braunii (Spenn.) Fée.-Tai-pei-shan, nos. 40, 51, 59.

52. P. craspedosorum (Maxim.) Diels var. Giraldii Christ (?).No. $5^{2}$ in part.

53. * Polystichum gracilipes, sp. nov.-Tai-pei-shan, nos. I 7, 3 I.

54. P. lachenense (Hook.) Bedd.-Tai-pei-shan, no. 46.

55. P. moupinense (Franch.) Bedd.-Tai-pei-shan, nos. 36, 39, $53,65(?)$.

56. ${ }^{*}$ P. Thomsoni (Hk.) Bedd. -Tai-pei-shan, nos. 22, 33(?).

57. P. (Cyrtomium) falcatum (L.) Diels var. polypterum Diels(?).-Tai-pei-shan, nos. 8I, 86.

58. Pteris multifida Lam.- Tai-pei-shan, no. Ir.

59. *Woodsia lanosa Hook. var. attenuata, var. nov.-No. I9.

6o. W. polystichoides Eat.-Tai-pei-shan, nos. 23, 29, 4I.

6r. Lycopodium annotinum $\mathrm{L},-\mathrm{No}, 2$.

62. Selaginella sanguinolenta (L.) Spr.-No. 27.

63. S. Stauntoniana Spring.-No. 26.

\section{Remarks on some species with descriptions of the new forms}

Adiantum aristatum Christ, Bot. Gaz. 51:356. igir.A. monochlamys var. latedeltoidea Christ, Nuov. Giorn. Bot. Ital. N.S. 4:88. r897. - Tai-pei-shan, no. 79.

CHRIST has later identified his proposed variety with A. Davidi Franch. (see Bull. Soc. Bot. France Mém. r:62), but it differs from that species just as the recently described $A$. aristatum does.

Adiantum erythrochlamys Diels.-Tai-pei-shan, no. 78 .

Probably this is what CHRIST has named A. monochlamys typus elongatus (Nuov. Giorn. Bot. Ital. N.S. 4:88. 1897). It differs from the typical $A$. monochlamys Eat. in the completely entire margins of its pinnae and in its very large indusia.

Athyrium mongolicum (Franch.) Diels var. Purdomii, var. nov.-Habitu, magnitudine, rachi sursum complanața, alata typo similis, differt: rhizomate vix repente, apice squamis atrobrunneis nitidis linearibus longe acuminatis dense onusto; pinnis basi aequalibus, i.e., lacinia anteriore vix aucta; laciniis approximatis fere quadratis apice truncatis leviter crenato vel obtuse 
dentato; indusiis magnis persistentibus tenuibus, fere omnibus reniformibus, nonnulis breviter hippocrepiformibus, nullis rectis. same.

Shensi: Tai-pei-shan, Purdom no. I3 (type); no. 20 is apparently the

Athyrium Sargentii, sp. nov.-Rhizomate erecto, squamis latis rufo-brunneis vestito. Stipitibus dense fasciculatis pallidis, basi nigrescentibus incrassatis, $2-3 \mathrm{~cm}$. longis, nudis. Lamina lanceolata, $20 \mathrm{~cm}$. circiter longa, medio $6-7 \mathrm{~cm}$. lata, utrinque attenuata, tenuiter membranacea, laete viridi, bipinnatifida. Rachi gracili, supra sulcata et pilis pluricellularibus mollibus pubescente. Pinnis I5-20-jugis, sessilibus, recte patentibus, inferioribus reductis et reflexis, medialibus maximis, $3-3 \cdot 5 \mathrm{~cm}$. longis, vix $\mathrm{I} \mathrm{cm}$. latis, oblongis, basi vix auriculatis, ad costas costulasque utrinque sparse hirtis, profunde pinnatifidis. Lobis patentibus sinubus acutis separatis, integris vel leviter crenatis, apice obtusis vel truncatis. Venis 4-jugis, simplicibus, ascendentibus. Soris $3-6$ in lobo, medialibus; indusiis brevibus (vix $2 \mathrm{~mm}$. longis), lineari-ovatis vel ovatis, turgidis, pallidis, marginibus integris, persistentibus, nullis hippocrepiformibus, nullis reniformibus.

Shensi: Tai-pei-shan, Purdom no. ro. This new species of the group of $A$. acrostichoides (Sw.) Diels stands between $A$. Giraldii Christ and $A$. mongolicum (Franch.) Diels. It resembles the former, which I have not seen, in its basal scales, the inflated bases of the stipes, and in the shape of the indusia, but it is much smaller and its segments are not triangular-falcate. From A. mongolicum, which it resembles closely in size, cutting, and general habit, it differs in its basal scales, the rachis not being winged upward, and especially in the totally different indusia.

Cheilanthes lanceolata, sp. nov.-Aleuritopteris rhizomate breve crasso, apice squamis rigidis lanceolatis brunneis marginibus pallidis 3-4 mm. longis dense onusto. Stipitibus fasciculatis, ad $10 \mathrm{~cm}$. longis, teretibus, strictis, fragillimis, atropurpureis, nitidis, squamis late-ovatis tenuissimis pallide brunneis deciduis instructis. Lamina lanceolata, ad $20 \mathrm{~cm}$. longa, medio $5-6 \mathrm{~cm}$. lata, versus basin paullulum angustata, tripinnatisecta, pilis squamisque omnino destituta, pagina inferiore farina alba subdense obtecta- superiore ut rachi glandulosa. Pinnis valde remotis, usque ad ro-jugis, infimis saepe abbreviatis, maximis $3-4 \mathrm{~cm}$. longis, deltoideis vel deltoideo- 
oblongis, sessilibus, obtusis vel acutis. Pinnulis $4-5$-jugis, ovatis vel oblongis, obtusis, inferioribus late adnatis $\mathrm{I} \mathrm{cm}$. longis, $5^{-7} \mathrm{~mm}$. latis, superioribus decurrentibus, versus apicem pinnarum confluentibus, profunde lobatis. Lobis ovatis, obtusis, maximis crenatis. Indusiis subcontinuis, leviter fimbriatis vel potius erosis, pallide-luteis.

Shensi: Tai-pei-shan, Purdom nos. 24 and 25. A most distinct species of $\S$ ALEURITOPTERIS, characterized by the lanceolate shape of the lamina, which is entirely destitute of hairs and scales. In general habit it resembles not a little the Mexican C. aurantiaca (Cav.) Moore, although the pinnae are somewhat more divided. The stipe and rachis are very fragile.

\section{Cystopteris moupinensis Franch.-Tai-pei-shan, nos. I4 and 63.}

No doubt specifically different from $C$. sudetica A. Br.; the indusia are eglandulose.

Dryopteris LACERA (Thunb.) O. Ktze.-No. 68.

Very typical. A. filix-mas var. Giraldii Christ, Nuov. Giorn. Bot. Ital. N.S. 4:94. 1897 is no doubt this species.

Dryopteris Purdomii, sp. nov.-Lastrea rhizomate (?), stipitibus ad $10 \mathrm{~cm}$. longis stramineis gracilibus, supra bisulcatis et decidue hirtis. Lamina anguste lanceolata, $30-35 \mathrm{~cm}$. longa, medio vix $5 \mathrm{~cm}$. lata, utrinque attenuata membranacea, bipinnatifida. Rachi gracili straminea, pilis albis brevibus patentibus deciduis sparse pubescente. Pinnis inferioribus $2-3$-jugis abbreviatis, $\mathrm{I}-2 \mathrm{~cm}$. longis, inter se $7 \mathrm{~cm}$. remotis, medialibus maximis 3-4 cm. longis, basi $\mathrm{I} .2-\mathrm{I} .4 \mathrm{~cm}$. latis, sessilibus, $3 \mathrm{~cm}$. inter se remotis, e basi latiore versus apicem breviter acuminatum sensim attenuatis, plerumque curvatim erectis, supra pilis brevibus antrorsis praesertim ad costas costulasque setulosis, infra ad costas costulasque pilis patentibus albidis subdense hispidulis, marginibus ciliatis, ad alam I mm. latam pinnatifidis. Laciniis obliquis, triangulari-acutis, marginibus revolutis integris, basali superiore parum longiore. Venis indivisis, ca. 5-jugis, obliquis, basalibus marginem supra sinum acutum attingentibus. Soris medialibus, numerosis, exindusiatis, receptaculo piloso, sporangiis setosis. 
Shensi: Tai-pei-shan, PuRDom no. 44. Most like a very narrow form of D. brunneo-villosa (Wall.) C. Chr., which it resembles in pubescence and in its triangular-oblong pinnae; but it is much smaller, and its setose receptacles and sporangia mark it clearly. D. rufostraminea (Christ) C. Chr. has similar pilose sori, but, according to the description, it is not very much like our plant.

Dryopteris sericea, sp. nov.-Eudryopteris rhizomate (?), stipitibus strictis, griseis, glabris, ad $10 \mathrm{~cm}$. longis, basi squamis rufis tenuibus ovato-acuminatis integris dense onustis. Lamina ovatooblonga, $25 \mathrm{~cm}$. longa, Io-1 $2 \mathrm{~cm}$. lata, versus apicem pinnatifidum sensim attenuata, basi rotundata, textura crassa, opaca, in siccitate supra brunnea infra grisea, ubique pilis articulatis brevissimis in aetate omnibus deciduis dense griseo-tomentella, bipinnatifida vel potius subbipinnata. Rachi griseo-straminea, superne sulcata, in parte inferiore squamis brunneis minutis sparse vestita. Pinnis 7-ro-jugis, adscendentibus, alternis, inferioribus $4-5$-jugis breviter petiolatis, superioribus sessilibus, late-oblongis, maximis ad $6 \mathrm{~cm}$. longis, $2-2.5 \mathrm{~cm}$. latis, latere posteriore paullulum latiore saepe inaequilateralibus, ad apicem breviter acuminatum vel non raro obtusum serratum e medio sensim attenuatis. Segmentis secundi ordinis basalibus pinnarum inferiorum liberis, basi cordatis et utrinque auriculatis auriculis brevibus obtusis, sequentibus is aequalibus, $1.5 \mathrm{~cm}$. longis, $5 \mathrm{~mm}$. latis, basi posteriore decurrentibus, anteriore auriculatis, marginibus crenatis vel interdum lobatis, superioribus ala $\mathrm{Imm}$. lata connectis, omnibus obtusissimis. Venis furcatis vel bifurcatis, 6-8-jugis. Soris medialibus; indusiis reniformibus, rufis, subglabris, persistentibus. Sporangiis glabris.

Shensi: North of Sian Fu, Tsin-ling Range, PuRDom no. 66. A most distinct fern, in its peculiar pubescence unlike all other species of Eudryopteris, to which subgenus it no doubt belongs. The whole frond is clothed with very short articulated hairs resembling those occurring in the subgenus CTENITIS; they are found equally throughout the surfaces and not mainly confined to the costae above as in Crenrirs; the costae are, like the veins, scarcely visible from the upper side. In venation, especially in the decurrent secondary veins, in color, indusium, and basal scales, our species agrees with most species allied to $D$, filix-mas; in general habit it resembles not a little $D$. cristata. The type specimen consists of three fronds, of which two are pubescent as described, while the third is absolutely glabrous, but otherwise perfectly similar to the two others; it is probably an older leaf with all the hairs fallen. As in several other species of the same relationship, the lower 2 or 3 pairs of pinnae are.
sterile. 
Gymnopteris bipinnata Christ in Lecomte, Not. Syst. $\mathbf{I}: 55$. I909. -Gymnogramme Delavayi Christ, Nuov. Giorn. Bot. Ital. N.S. 4:17. pl. 3. fig. 3 (non BAKER).-Tai-pei-shan, no. 28.

Matteuccia intermedia, sp. nov.-Species critica inter $M$. struthiopteridem et $M$. orientalem medium tenens, a priore quae habitu magnitudine similis, differt: paleis basalibus nigris, rachibus paleaceis, lamina longe stipitatis, versus basin breviter decrescente, pinnis lobatis nec profunde pinnatifidis, venis tertiariis circiter 5-jugis, pinnis fertilibus $6-7 \mathrm{~cm}$. longis, $3-4 \mathrm{~mm}$. latis recurvatis; a posteriore, quae venatione, colore, rachi paleacea similis, differt; pinnis angustioribus, inferioribus $2-3$-jugis abbreviatis.

A most critical form, intermediate between $M$. struthiopteris (L.) Tod. and $M$. orientalis (Hook.) Trev. The sterile leaf resembles $M$. struthiopteris in size and in breadth of pinnae; it differs in (I) the long stipe, which is up to $20 \mathrm{~cm}$. long, $0.5 \mathrm{~cm}$. or more thick, broadly furrowed above, in the lower part and especially at base clothed with large $(2 \mathrm{~cm}$. long by $0.5 \mathrm{~cm}$. wide), nearly black, glossy, and entire scales; (2) the lamina being very shortly attenuate downwards, the lower 2 pairs of pinnae only being somewhat abbreviated; (3) the rachis, like the costae of the pinnae beneath, clothed with several minute blackish scales; (4) the pinnae, which are not very close, linear, $10-12 \mathrm{~cm}$. long by $1.5 \mathrm{~cm}$. broad, incised not more than a third of the way down to the midrib into broad, obtuse lobes; basal lobes scarcely prolonged, but the lower one considerably broader and imbricating the upper side of the rachis, under surface pale, glandular with scattered yellowish glands; (5) the venation, the tertiary veins being very oblique, about 5 to a side, the lower ones curved upward and running to the sinus. M. orientalis has much broader and more deeply cut pinnae, the basal ones not at all abbreviated. Fertile leaf with stipe and rachis rather scaly beneath with light-brown, crisped scales; stipe 20$30 \mathrm{~cm}$. long, lamina $40-50 \mathrm{~cm}$. long, about $10 \mathrm{~cm}$. broad; lower pinnae a little shortened, median ones $6-7 \mathrm{~cm}$. long, $3-4 \mathrm{~mm}$. broad, at first erect, later recurved from the erect base with hanging tips; costae scaly beneath, the veins distinctly seen on the upper side. Indusium apparently wanting.

As a whole, our new species is perhaps nearest to $M$. orientalis, resembling it in color, the scaly rachis, and especially in the large fertile leaves, but in general habit it is much more like $M$. struthiopteris. It is possible that Struthiopteris orientalis var. brevis Christ, Bull. Soc. Bot. France, Mém. r:44, from Szechuan and Hupeh, is just our species. Shensi: Tai-pei-shan, PuRDoM nos. I, 8, 9, I 2.-Recently I have received from Professor BowER, of Glasgow, a very similar exindusiate form from Darjeeling, Sikkim, British Himalaya, leg. W. CAve.

Polypodium clathratum Clarke in Trans. Linn. Soc. II. Bot. I:559. pl. 82. fig. I. I880.-Tai-pei-shan, no. $9^{6 .}$ 
The young sori are perfectly concealed by large, appressed, thin, peltate scales, which in the mature sori appear as a lacerated, blackish network between the sporangia. This network (clathrate scales) is formed from the thin, peltate scales by the outer (surface) cell-walls having been dissolved, while the remaining cross-walls become thick and black.

Polypodium eilophyllum Diels.- $P$. Lewisii Christ, Nuov. Giorn. Bot. Ital. N.S. 4:97. pl. I. fig. I (non BAKeR).-No. 90.

Polystichum gracilipes sp. nov.-Species parva e grege $P$. deltodon (Bak.) Diels rhizomate erecto, squamis angustis fulvis sparse vestito. Stipitibus fasciculatis, gracilibus, ad $6 \mathrm{~cm}$. longis, vix $\mathrm{r} \mathrm{mm}$. crassis, stramineis, versus basin squamis parvis ovatoacuminatis breviter fimbriatis onustis, sursum rotundis. Lamina lanceolata, simpliciter pinnata, Io- $15 \mathrm{~cm}$. longa, vix $2 \mathrm{~cm}$. lata, subtus pallide viridi, subcoriacea, rachi tenui, squamis parvis ovato-lanceolatis longe acuminatis fimbriatis deciduis praedita. Pinnis 20-25-jugis, approximatis, brevissime petiolulatis, quadrangularibus, 8-ro $\mathrm{mm}$. longis, $4-5 \mathrm{~mm}$. latis, basi posteriore cuneata anteriore auriculata, marginibus dentatis, dentibus cuspidatis; pinnis inferioribus parum abbreviatis; pagina inferiore squamis minutis sparse obtecta. Soris inter costam et marginem medium tenentibus vel saepe costae magis approximatis; indusiis magnis, persistentibus, glabris, subintegris.

Shensi: Tai-pei-shan, PuRDom nos. 17 and 3 I. Closely related to $P$. lanceolatum (Bak.) Diels, from which it differs in its longer stipe, scaly rachis, auricled upper base of the pinnae, and large, persistent sori. Both edges of the pinnae bear about 5 cuspidate teeth each.

Woodsia LANOSA Hook. var. attenuata, var. nov.-A typo differt: lamina versus basin sensim attenuatis; pinnis inferioribus minutis; stipitibus vix $2 \mathrm{~cm}$. longa, lamina $5^{-6} \mathrm{~cm}$. longa, $1 \mathrm{~cm}$. lata; pinnis oblongis nec ovatis.

Shensi: Tai-pei-shan, Purdom no. 19. Perhaps a new species. The whole frond is very densely covered with long grayish hairs, those of the rachis and costae beneath intermixed with some very thin, narrow, hyaline scales. The rather thick and short rhizome is densely clothed with broad, red scales.

Copenhagen 


\section{$2 \mathrm{BHL}$ Biodiversity Heritage Library}

Christensen, Carl. 1913. "Filices Purdomianae." Botanical gazette 56(4), 331-338. https://doi.org/10.1086/331170.

View This Item Online: https://www.biodiversitylibrary.org/item/39605

DOI: https://doi.org/10.1086/331170

Permalink: https://www.biodiversitylibrary.org/partpdf/223527

\section{Holding Institution}

Missouri Botanical Garden, Peter H. Raven Library

\section{Sponsored by}

Missouri Botanical Garden

\section{Copyright \& Reuse}

Copyright Status: Public domain. The BHL considers that this work is no longer under copyright protection.

This document was created from content at the Biodiversity Heritage Library, the world's largest open access digital library for biodiversity literature and archives. Visit BHL at https://www.biodiversitylibrary.org. 